\title{
Distribution of Breast Density in Iranian Women and its Association with Breast Cancer Risk Factors
}

\author{
Nasrin Ahmadinejad ${ }^{1}$, Sajjadeh Movahedinia ${ }^{2,}{ }^{,}$, Samaneh Movahedinia ${ }^{3}$, Kourosh \\ Holakouie Naieni ${ }^{4}$, Saharnaz Nedjat ${ }^{4}$, Masumeh Gity ${ }^{1}$, Maryam Rahmani ${ }^{1}$ \\ ${ }^{1}$ Advanced Diagnostic and Interventional Radiology Research Center (ADIR), Tehran University of Medical Sciences (TUMS), Tehran, IR Iran \\ ${ }_{3}^{2}$ Department Pathology, Iran University of Medical Sciences (IUMS), Tehran, IR Iran \\ ${ }^{3}$ School of Medicine, Tehran University of Medical Sciences (TUMS), Tehran, IR Iran \\ ${ }^{4}$ Epidemiology and Biostatistics Department, School of Public Health, Tehran University of Medical Sciences (TUMS), Tehran, IR Iran \\ ${ }^{*}$ Corresponding Author: Sajjadeh Movahedinia, Advanced Diagnostic and Interventional Radiology Research Center (ADIR), Tehran University of Medical Sciences (TUMS), Imam \\ Khomeini Hospital, Tehran, Iran. Tel: +98-2166581577, E-mail: sj_movahedi@yahoo.com
}

Received: February 22, 2013; Revised: June 25, 2013; Accepted: August 27, 2013

\begin{abstract}
Background: Breast cancer is one of the most common cancers and the first-leading cause of cancer deaths among women in the world. Indeed, breast cancer is ranked as the first malignancy among Iranian women. Breast density, defined as the percentage of fibro glandular breast tissue in mammographic images, is one of the known risk factors for breast cancer. According to American college of radiologyBreast Imaging Reporting and Data System(ACR-BIRADS), mammographic density is divided into four categories. Studies have shown that increased breast density is associated with significant increase in breast cancer risk. Therefore, it is assumed that breast density should be associated with other breast cancer risk factors.

Objectives: The aim of this study was to assess the epidemiologic distribution of breast density of the patients in a referral center in Iran, and to evaluate the association of high breast density and breast cancer risk factors and other factors that may possibly affect the mammographic density according to previous studies.

Patients and Methods: In an analytical cross-sectional study, 728 of those who had referred to Imam Khomeini Imaging Center either for diagnostic or screening purposes, participated in the study, after filling out the informed consent form, the survey questionnaire based survey assessing breast cancer risk factors affecting the breast density and related demographic features, was conducted. SPSS 11.5 software and chi-square, t-test and logistic regression tests were used to analyze the data.

Results: Most of patients (75\%) in categories 2 and 3 of mammographic density had a breast density of 51.9\%, however, this amount was less (49.2\%) in screening mammograms, while in diagnosing group it was more (51.6\%). The Findings showed an increase in age, body mass index (BMI), duration of breast feeding, and also to be menopause e, unemployed and married, younger than 29 years old at first delivery, having children up to 8 and smoking are associated with less breast density. Diagnostic mammograms and symptomatic patients showed denser breasts. But density had no association with oral contraceptives pill (OCP) consumption or hormone replacement therapy or calcium and/or vitamin D consumption, age at menarche and menopause, menstruation cycle phase and family history of breast cancer. Age at the first delivery, menopausal status and parity were independently associated with breast density.

Conclusions: Density distribution and risk factors prevalence is different among symptomatic patients and the diagnostic mammograms of the screened persons, hence such information should be considered in the patient managements. In order to consider the effect of marriage and parity on decreasing the breast density, basic consultations should be performed. Smokers and obese women may falsely show low breast density while they may be in high-risk group. In this study no specific phase of menstrual cycle is suggested for mammographic examinations.
\end{abstract}

Keywords: Breast Neoplasms; Mammography; Mass Screening

\section{Background}

Cancer is one of the leading causes of mortality worldwide (about 13\% of all mortalities) (1) and its incidence has globally increased to more than two times during the past 30 years (2). Breast cancer is one of the most common cancers amongst women worldwide (about 23\% of all cancers) and it is the first cause of mortality due to cancer among women (3). The annual incidence of breast cancer is steadily increasing and this ascending process has a higher rate in countries with low breast cancer incidence (4). In Iran, breast cancer is the most common cancer among women, and studies have shown that it accounts for $24.4 \%$ of all neoplasms (5) with a crude incidence rate of $17.81(6,7)$.

Breast cancer incidence is increasing in Iran. Despite development of diagnostic methods, still many patients are diagnosed at developed stages $(8,9)$, Based on the

Implication for health policy/practice/research/medical education:

Kindly write a proper statement.

Copyright (C) 2013, Iranian Red Crescent Medical Journal; Published by Kowsar Corp. This is an open-access article distributed under the terms of the Creative Commons Attribution License, which permits unrestricted use, distribution, and reproduction in any medium, provided the original work is properly cited. 
comparative reports, the mean age of Iranian women with breast cancer (with a mean age of 47.1 to 48.8 ) is at least 10 years younger than the women with the same malignancy in developed countries $(8,10)$. Thus, the early diagnosis of breast cancer plays an important role in a better prognosis and consequently leaded to a reduced mortality rate. Mammography, as the method of choice for population-based breast cancer screening, aims to detect cancer at asymptomatic stages that the treatment is easier with better outcomes (11). The screening programs in some countries have proved this claim (12).

Various environmental and genetic factors have been approved to affect the susceptibility of breast cancer. According to 2008 WHO report, breast cancer is associated with nulliparity, first delivery at an old age, early menarche and late menopause. Using oral contraception pills (OCP) and Hormone Replacement Therapy (HRT) are also reported to be associated with an increased risk of breast cancer. Family history of breast cancer and high mammography density are two breast cancer risk factors which help to detect high risk women in screening programs (2).

As mentioned before, mammography is the recommended screening method for early detection of breast cancer which has a high potency in detecting suspicious lesions. On the other hands, it helps to identify high risk women by determining mammographic breast density. Breast density higher than $75 \%$ is associated with a $4-6$ folds increase in breast cancer risk $(13,14)$.

There are several methods to estimate mammographic density of mammograms including qualitative methods such as Wolfe grade, BIRADS classification, Tabar grade, and six-category classification, as well as quantitative method (computer-assisted threshold method) (15). Qualitative methods are observer-base but these methods do not have the limitations that the quantitative methods do, for instance, the tumor volume assessment and estimation from two-dimensional images is possible, because the observer can reconstruct a three-dimensional image of the breast and densities, out of images taken in two different views, in his mind. On the other hand, many common $(16,17)$ and uncommon $(18,19)$ benign and malignant lesions may be presented as dense lesions in mammography images that may be ignored in qualitative methods by the physician when estimating the underlying breast tissue density, but this would not be happened using automated methods. In large or multiple lesion cases, the breast density will be falsely diagnosed.

New methods are being developed to minimize such limitations. Further studies should be done to prove the density, estimated by these methods (15). One the most common qualitative methods used to define the breast density is BIRADS classification which was also used in our study.

\section{Objectives}

We expect a higher breast density in women at higher risk of breast cancer, thus it would be associated with other breast cancer risk factors. Few studies have been performed on mammographic density in Iran (20-22), none of which have been allocated to the epidemiologic distribution of mammographic density. Regarding the difference in prevalence of dense breasts and life style in each population, the determinants of breast density differ in each country. So we decided to assess the distribution of this factor among Iranian population and evaluate its association with other risk factors and factors that may affect breast density based on previous studies.

\section{Materials and Methods}

\subsection{Study Design and Sampling}

This was an analytical cross-sectional study carried out in Tehran, Iran in order to estimate breast density distribution and investigate its determinants in Iranian women. 728 of those who had referred to imaging center of Imam Khomeini Cancer Institute either for diagnosing or screening purposes, were participated in this study, after filling out the informed consent form, the questionnaire based survey, assessing breast cancer risk factors affecting the breast density and related demographic features, was conducted. Inclusion criteria: Accessibility to mammographic report, including mammographic density, reported by one of the three radiologists participating in this study. Exclusion criteria: Individuals with a history of bilateral breast cancer were excluded from the study. Cases with a history of unilateral breast cancer, the mammographic information of the contra lateral breast was included in the analysis. Those who had not filled out the informed consent form or the questionnaire or had no accessible mammographic information were excluded.

\subsection{Sample Size}

Based on the prevalence of dense breasts in literature $(23,24)$, the minimum estimated sample size, was 380 that was increased to 800, considering the design effect (with the assumption of 2 for DF and a power of $80 \%$ at $5 \%$ significance level). Sixty three questionnaires were not filled out, that indicate a response rate of around 92\%.

\subsection{Measures}

According to literature, different variables which may affect the breast density and breast cancer risk factors were determined and demographic questionnaire was designed. This was a 20-item questionnaire including 
questions of ages, weight, height, marital status, occupational status, obstetric information (menarche age, menopause age, parity number, age at first delivery, etc.) breast cancer risk factors (personal and family history of breast cancer, OCP consumption, etc.) and other factors seem to affect density (ovarian cycle phase, using calcium, etc.).

During one month, about 60 patients participated in a pilot study and evaluations regarding missed data were conducted. Necessary revisions were taken into account to decrease missed data.

Mammographic density was reported by three expert radiologists using BI-RDAS standards lexicon. According to BIRADS lexicon breast density is classified into four groups: ACR I (almost entirely fat or fibro glandular tissue (FGT) $<25 \%$ ), ACR II (scattered fibro glandular densities or FGT of 25-50\%), ACR III (heterogeneously dense or FGT of 50-75\%) and ACR IV (extremely dense or FGT > 75\%) (25). Reporters are all colleagues who work in the same center. All mammograms (full-digital two-view ones) were taken with the same technique and read on the same system.

\subsection{Analysis}

More than one observer participated in the study; an assessment of the inter-observer agreement was required to analyze the data. In another study, conducted by the authors in the same center, inter and intra-observers variability in interpreting mammograms was evaluated by three radiologists. Based on the results of this study, inter-observer agreement in reporting density is good (kappa $=0.701)$. Our results are comparable with another study that recently carried out in Isfahan, Iran (11), showing an extensive agreement among reporters in defining the type of density (Kappa $=0.74)$. So, it was reasonable to perform one analysis for all samples. This procedure was separately done in both diagnostic and screening groups. Descriptive statistics including frequency, percentage, mean and standard deviations were used to describe the study sample.

The dependent variable (mammographic density) was categorized into two levels: low density breast tissue (breast density of ACR groups 1 and 2) and high density breast tissue (breast density of ACR groups 3 and 4). The independent variables were compared in groups. To compare the continuous data, t-test was used. The association of categorical data and density was analyzed by chisquare and Fisher's exact test. For categorical data another analysis using t-test was performed to compare mean density percentage between the two groups. A P-value of less than 0.05 was considered statistically significant. Both univariate and multiple logistic regression analysis were performed to examine the association between density and independent variables. Data were analyzed using the SPSS statistics software version 11.5. The study has been approved by the ethics committee of Tehran University of Medical Sciences. The written informed assent was taken from all participators.

\section{Results}

\subsection{The Study Sample}

728 women participated in the study amongst 184 (25.3\%) had undertaken mammography for diagnostic and $542(74.7 \%)$ for screening purposes. Out of 542 patients, 210 (38.7\%) mammograms were done for the first time and 332 (61.3\%) for follow up.

The mean age of participants was $48.12(\mathrm{SD}=8.66)$ ranging from 19 to 83 years. Participants' age distribution had normal distribution. $57.1 \%$ of participants had one of the symptoms including pain, feeling mass or thickness in the breast, bloody or watery discharge, pruritus, erythema or nipple retraction. $37.4 \%$ of them experienced the symptoms in left, $28.8 \%$ in the right breast and $33.8 \%$ have bilaterally pain. $57.8 \%$ of the patients in screening group were asymptomatic and $2.2 \%$ were in diagnostic group. $94.1 \%$ of the study sample were married; 41 (5.6\%) had personal history of breast cancer and 170 (24.5\%) had positive family history of breast cancer. The demographic features of the samples are shown in Table 1. There was a significant difference between diagnostic and screening groups in some factors including age, breast density, personal history of breast cancer, using HRT and menopausal status.

\subsection{Breast Density Distribution Among Partici- pants}

The Mean mammographic density of the participants was estimated $48.9 \%$, in the categories four of ACR mammographic density these amounts were $15.3 \%, 32.8 \%, 42.8 \%$ and $9.1 \%$ respectively. Most of the patients (75\%) were among categories 2 and 3 of mammographic density and dense breasts (ACR 3 and 4 ) were 51.9\%; however this amount was lessened in screening mammograms (49.2\%) and in diagnostic group were even more (51.6\%), but statistically significant difference was observed $(\mathrm{P}=0.017$, $\mathrm{OR}=0.66,95 \mathrm{CI}=0,47-0,93)$. The mean density in diagnostic and screening group was $52.5 \%$ and $47.7 \%$ respectively and t-test showed significant difference between them (P $=0.009, \mathrm{~T}=2.619$ ).

\subsection{Factors Affecting Breast Density}

Age: the distribution of breast density in different aging groups shows that in younger age groups (15-50 years old) high density breasts were more than low density breasts and in older age groups (51-58 years old) this pro- 
Ahmadinejad $\mathrm{N}$ et al.

portion is reversed and the difference of dense breasts between the two age groups is significant $(\mathrm{P}<0.001)$. On the other hand the results showed that in both screening and diagnostic groups, the mean age is significantly different in both groups of high and low density breasts. Table 2 separately compares different risk factors according to breast density in both diagnostic and screening groups.

Table 1. Demographic Feature of the Study

\begin{tabular}{|c|c|c|c|c|}
\hline & $\begin{array}{l}\text { Total }(n=728) \text { Mean } \\
\pm \text { SD }\end{array}$ & $\begin{array}{l}\text { Screening }(\mathrm{n}=544) \\
\text { Mean } \pm \text { SD }\end{array}$ & Diagnostic Mean \pm SD & $\operatorname{POR}(95 \% \mathrm{CI})$ \\
\hline $\operatorname{Age}(y)$ & $48.1 \pm 8.6$ & $48.6 \pm 8.3$ & $46.6 \pm 9.4$ & 0.012 \\
\hline BMI & $27.9 \pm 5.4$ & $27.8 \pm 4.8$ & $28.3 \pm 7.0$ & 0.408 \\
\hline Density (percent) & $48.9 \pm 21.5$ & $47.7 \pm 21.4$ & $52.5 \pm 21.3$ & 0.009 \\
\hline Menarche age & $13.5 \pm 1.5$ & $13.5 \pm 1.5$ & $13.5 \pm 1.4$ & 0.594 \\
\hline Parity number & $2.8 \pm 1.8$ & $2.8 \pm 1.7$ & $3.0 \pm 2.3$ & 0.140 \\
\hline First birth age & $21.5 \pm 4.8)$ & $21.6 \pm 4.8$ & $21.1 \pm 4.7$ & 0.268 \\
\hline Menopause age & $47.2 \pm 5.6$ & $47.3 \pm 5.4$ & $47.1 \pm 6.2$ & 0.890 \\
\hline $\begin{array}{l}\text { FH of breast cancer } \\
\text { positive }\end{array}$ & & & & 0.087 \\
\hline First degree & $70 \pm 10.1$ & $57 \pm 10.9$ & $13 \pm 7.5$ & \\
\hline Second degree & $87 \pm 12.5$ & $68 \pm 13.1$ & $19 \pm 11.0$ & \\
\hline Both & $13 \pm 1.9$ & $11 \pm 2.1$ & $2 \pm 1.2$ & \\
\hline Negative & $524 \pm 75.5$ & $385 \pm 73.9$ & $139 \pm 80.3$ & \\
\hline $\begin{array}{l}\text { FH of other cancers } \\
\text { positive }\end{array}$ & & & & 0.123 \\
\hline First degree & $73 \pm 11.3$ & $56 \pm 11.5$ & $17 \pm 10.3$ & \\
\hline Second degree & $69 \pm 10.8$ & $57 \pm 11.7$ & $12 \pm 7.2$ & \\
\hline$>1$ positive $\mathrm{FH}$ & $18 \pm 3.1$ & $17 \pm 3.4$ & $138 \pm 83.1$ & \\
\hline Negative & $513 \pm 78.9$ & $375 \pm 77.5$ & $1 \pm 0.6$ & \\
\hline $\begin{array}{l}\text { Personal Hx of breast } \\
\text { cancer }\end{array}$ & & & & $0.046,2.55(0.98-6.6)$ \\
\hline Positive & $41 \pm 5.6$ & $36 \pm 6.6$ & $5 \pm 2.7$ & \\
\hline Negative & $687 \pm 94.4$ & $508 \pm 93.4$ & $179 \pm 97.3$ & $2.55(0.98-6.6)$ \\
\hline Marital status & & & & 0.850 \\
\hline Single & $41 \pm 5.9$ & $30 \pm 5.8$ & $11 \pm 6.2$ & \\
\hline Married & $651 \pm 94.1$ & $485 \pm 94.2$ & $166 \pm 93.8$ & \\
\hline Breast feeding yes & & & & 0.510 \\
\hline Complete & $379 \pm 60.9$ & $285 \pm 60.0$ & $94 \pm 63.9$ & \\
\hline Incomplete & $176 \pm 28.3$ & $141 \pm 29.7$ & $35 \pm 23.9$ & \\
\hline Never & $67 \pm 10.8$ & $49 \pm 10.3$ & $18 \pm 12.2$ & \\
\hline Using OCP yes & & & & 0.895 \\
\hline Already & $229 \pm 36.9$ & $180 \pm 37.3$ & $49 \pm 35.5$ & \\
\hline Still yes & $17 \pm 2.7$ & $12 \pm 2.5$ & $5 \pm 3.6$ & \\
\hline Never & $375 \pm 60.4$ & $291 \pm 60.2$ & $84 \pm 60.9$ & \\
\hline Using HRT yes & & & & $0.033,2.70(1.05-6.98)$ \\
\hline Already & $23 \pm 3.2$ & $22 \pm 4.0$ & $1 \pm 0.5$ & \\
\hline Still yes & $20 \pm 2.7$ & $16 \pm 3.0$ & $4 \pm 2.2$ & \\
\hline Never & $683 \pm 94.1$ & $504 \pm 93.0$ & $179 \pm 97.3$ & \\
\hline Using Ca/Vitamin D & & & & 0.176 \\
\hline $\mathrm{Ca}$ & $14 \pm 1.9$ & $12 \pm 2.2$ & $2 \pm 1.1$ & \\
\hline
\end{tabular}


Ahmadinejad $N$ et al.

\begin{tabular}{|c|c|c|c|c|}
\hline Both & $8 \pm 1.1$ & $4 \pm 0.7$ & $4 \pm 2.2$ & \\
\hline None & $706 \pm 97.0$ & $528 \pm 97.1$ & $178 \pm 96.7$ & \\
\hline Menopausal status & & & & $0.004,1.70(1.18-2.44)$ \\
\hline Yes & $274 \pm 37.7$ & $221 \pm 40.7$ & $53 \pm 28.8$ & \\
\hline No & $453 \pm 62.3$ & $322 \pm 60.3$ & $131 \pm 71.2$ & \\
\hline Employment status & & & & 0.437 \\
\hline Not employed & $479 \pm 77.0$ & $367 \pm 76.3$ & $112 \pm 79.4$ & \\
\hline Occupied & $111 \pm 17.9$ & $86 \pm 17.9$ & $25 \pm 17.8$ & \\
\hline Retired & $32 \pm 5.1$ & $28 \pm 5.8$ & $4 \pm 2.8$ & \\
\hline Smoking & & & & 0.962 \\
\hline No & $469 \pm 72.2$ & $361 \pm 72.2$ & $108 \pm 72.0$ & \\
\hline $\begin{array}{l}\text { Yes, passive } \\
\text { smoker }\end{array}$ & $161 \pm 24.7$ & $123 \pm 24.6$ & $38 \pm 25.3$ & \\
\hline Smoker & $20 \pm 3.1$ & $16 \pm 3.2$ & $4 \pm 2.7$ & \\
\hline Radiotherapy Hx & & & & 0.335 \\
\hline Yes & $43 \pm 6.0$ & $35 \pm 6.5$ & $8 \pm 4.5$ & \\
\hline No & $670 \pm 94.0$ & $502 \pm 93.5$ & $168 \pm 95.5$ & \\
\hline $\begin{array}{l}\text { Mammographic } \\
\text { density }\end{array}$ & & & & $0.017,0.66(0.47-0.93)$ \\
\hline Low density ACR I & $108 \pm 15.3$ & $87 \pm 16.5$ & $21 \pm 11.8$ & \\
\hline ACR II & $231 \pm 32.8$ & $180 \pm 34.3$ & $51 \pm 28.6$ & \\
\hline $\begin{array}{l}\text { High density ACR } \\
\text { III }\end{array}$ & $301 \pm 42.8$ & $217 \pm 41.2$ & $84 \pm 47.2$ & \\
\hline ACR IV & $64 \pm 9.1$ & $42 \pm 8.0$ & $22 \pm 12.4$ & \\
\hline
\end{tabular}

\subsection{Breast Feeding}

The chi-square test showed no significant difference in breast feeding behaviors in two breast density groups, but t-test proved that mean density was significantly higher in those without any history of breast feeding (56.7\%) compared to those with a history of two years of breast feeding (48.9\%) or any duration of breast feeding (48.4\%) ( $\mathrm{P}=0.007$ and 0.003 respectively). T-test in diagnostic group showed no relation $(\mathrm{P}=0.071)$; but in screening group we found this relation $(\mathrm{P}=0.020)$.

\subsection{Menopausal Status}

Results in Table 2 shows there is association between menopausal status and density in both screening and diagnostic groups. Mean density of premenopausal women $(53.7 \%)$ was also significantly higher $(P<0.001)$ than menopausal women (41.1\%). The same results were driven from t-test in diagnostic $(\mathrm{P}<0.001)$ and screening groups $(\mathrm{P}<0.001)$.

\subsection{Marital Status}

Chi-square test determined an association between marital status and breast density in the screening but not the diagnostic group. However, t-test proved this relation to exist in both screening $(\mathrm{P}=0.001)$ and diagnostic $(\mathrm{P}=$
0.023 ) groups.

\subsection{Parity}

Analysis showed there is an association between nulliparity and dense breast tissue in diagnostic groups ( $\mathrm{P}$ $=0.044)$ but not in the screening one $(P=0.401)$. T-test showed there is a reverse relationship between parity number and breast density in both groups (Table 2). According to t-test comparing mean breast density in nullipar women (50.7\%) with other women (48.1\%), the difference was significant $(\mathrm{P}<0.001)$ and this relationship remains significant in higher parity number cut points,(up to the 8 th parity).

\section{8. $H R T$}

Cross tab analysis in screening and diagnostic groups, demonstrated that there was no significant association between breast density of those who currently and/or previously received HRT and those without a history of HRT. Indeed all the analyses were repeated only for menopausal women, which introduced the same result.

\subsection{OCP}

As showed in table 2, analysis presented no association between breast density and current and/or previous use 
Ahmadinejad $N$ et al.

of OCP in each group.

\subsection{Smoking}

In screening group, 51.3\% of those who had no expo- sure to the smoke (non-smokers) and 25\% of smokers had dense breasts and their difference was significant $(\mathrm{P}=0.040)$, but not in screening group. The Mean breast density among non-smokers was significantly higher (50.2\%) than smokers (37.5\%) $(\mathrm{P}=0.012)$.

\begin{tabular}{|c|c|c|c|c|c|c|}
\hline & \multicolumn{2}{|c|}{ Screening $(n=544)$ Mean \pm SD } & \multirow{2}{*}{$\begin{array}{l}\text { P-value OR (95\% } \\
\text { CI) }\end{array}$} & \multicolumn{2}{|c|}{ Diagnostic $(n=184)$ Mean \pm SD } & \multirow{2}{*}{$\begin{array}{l}\text { P-value OR (95\% } \\
\mathrm{CI})\end{array}$} \\
\hline & High Density & Low Densit & & High Density & Low Density & \\
\hline Age, (y) & $46.41 \pm 7.5$ & $50.78 \pm 8.4$ & $\begin{array}{l}<0.001^{\mathrm{a}}, \\
(\mathrm{t}=6.252)\end{array}$ & $44.39 \pm 8.3$ & $49.87 \pm 10.1$ & $\begin{array}{l}<0.001^{\mathrm{a}}, \\
(\mathrm{t}=3.914)\end{array}$ \\
\hline BMI & $26.82 \pm 4.76$ & $28.86 \pm 4.7$ & $\begin{array}{l}<0.001^{\mathrm{a}}, \\
(\mathrm{t}=4.294)\end{array}$ & $27.62 \pm 7.6$ & $29.58 \pm 5.6$ & $0.171^{\mathrm{a}},(\mathrm{t}=1.377)$ \\
\hline Menarche age & $13.53(1.5)$ & $13.59(1.4)$ & $0.667^{\mathrm{a}},(\mathrm{t}=0.431)$ & $13.50(1.4)$ & $13.96(4.3)$ & $0.341^{\mathrm{a}},(\mathrm{t}=0.954)$ \\
\hline Parity number & $2.35(1.5)$ & $3.19(1.7)$ & $\begin{array}{l}<0.001^{\mathrm{a}} \\
(\mathrm{t}=5.766)\end{array}$ & $2.48(1.9)$ & $3.86(2.6)$ & $\begin{array}{l}<0.001^{\mathrm{a}} \\
(\mathrm{t}=3.937)\end{array}$ \\
\hline First birth age & $22.67(5.0)$ & $20.59(4.4)$ & $\begin{array}{l}<0.001^{\mathrm{a}},(\mathrm{t}=- \\
4.578)\end{array}$ & $21.57(5.1)$ & $20.33(3.7)$ & $0.156^{\mathrm{a}},(\mathrm{t}=-1.426)$ \\
\hline \multicolumn{7}{|l|}{ Last birth age } \\
\hline Menopause age & $47.30(4.7)$ & $47.24(5.8)$ & $\begin{array}{l}0.944^{\mathrm{a}},(\mathrm{t}=- \\
0.071)\end{array}$ & $46.04(6.4)$ & $47.71(6.3)$ & $0.341^{\mathrm{a}},(\mathrm{t}=0.960)$ \\
\hline \multicolumn{7}{|l|}{$\begin{array}{l}\text { Ovarian cycle } \\
\text { length }\end{array}$} \\
\hline $\begin{array}{l}\text { FH of breast } \\
\text { cancer }\end{array}$ & & & & & & $0.516^{\mathrm{b}}$ \\
\hline Positive & $64(25.2)$ & $68(26.3)$ & $0.784^{b}$ & $18(18.0)$ & $15(22.1)$ & \\
\hline Negative & $190(74.8)$ & $191(73.7)$ & & $82(82.0)$ & $53(77.9)$ & \\
\hline $\begin{array}{l}\text { FH of Other } \\
\text { Cancers }\end{array}$ & & & $0.632^{b}$ & & & $0.074^{\mathrm{b}}$ \\
\hline Positive & $50(21.7)$ & $58(23.6)$ & & $20(21.1)$ & $7(10.4)$ & \\
\hline Negative & $180(78.3)$ & $188(76.4)$ & & $75(78.9)$ & $60(89.6)$ & \\
\hline $\begin{array}{l}\text { Personal Hx of } \\
\text { breast cancer }\end{array}$ & & & $0.925^{b}$ & & & $0.650^{c}$ \\
\hline Positive & $18(6.9)$ & $18(6.7)$ & & $4(3.8)$ & $1(1.4)$ & \\
\hline Negative & 241(93.1) & $249(93.3)$ & & $102(96.2)$ & $71(98.6)$ & \\
\hline Marital status & & & $\begin{array}{l}0.027^{\mathrm{b}}, 0.41(0.18- \\
0.92)\end{array}$ & & & $0.529^{C}$ \\
\hline Single & $20(8.0)$ & $9(3.5)$ & & $8(8.7)$ & $3(4.4)$ & \\
\hline Married & $229(92.0)$ & $250(96.5)$ & & $95(92.2)$ & $65(95.6)$ & \\
\hline Nulliparity & & & $0.401^{b}$ & & & $\begin{array}{l}0.044^{\mathrm{b}}, 0.23 \\
(0.05-1.08)\end{array}$ \\
\hline Yes & $22(9.4)$ & $18(7.3)$ & & $12(12.0)$ & $2(3.1)$ & \\
\hline No & $212(90.6)$ & $229(92.7)$ & & $88(88.0)$ & $63(96.9)$ & \\
\hline Breast feeding & & & $0.434^{\mathrm{b}}$ & & & $0.622^{\mathrm{b}}$ \\
\hline Yes & $202(88.6)$ & $217(90.8)$ & & $80(87.0)$ & $44(89.8)$ & \\
\hline Never & $26(11.4)$ & $22(9.2)$ & & 12 13.0) & $5(10.2)$ & \\
\hline Using OCP & & & $0.680^{b}$ & & & $0.957^{b}$ \\
\hline Yes & $93(39.1)$ & $140(59.1)$ & & $34(40.5)$ & $20(40)$ & \\
\hline Never & $145(60.9)$ & $97(40.9)$ & & $50(59.5)$ & $30(60)$ & \\
\hline
\end{tabular}


Ahmadinejad $N$ et al.

\begin{tabular}{|c|c|c|c|c|c|c|}
\hline Using HRT & & & $0.216^{\mathrm{b}}$ & & & $0.366^{c}$ \\
\hline Yes & $15(5.8) \mathrm{M}$ & $23(8.6)$ & & $2(1.9)$ & $3(4.2)$ & \\
\hline No & $243(94.2)$ & $244(91.4)$ & & $104(98.1)$ & $69(95.8)$ & \\
\hline Using calcium & & & $0.144^{\mathrm{b}}$ & & & $1.000^{C}$ \\
\hline Yes & $5(1.9)$ & $11(4.1)$ & & $4(3.8)$ & $2(2.8)$ & \\
\hline No & $254(98.1)$ & $256(95.9)$ & & $102(96.2)$ & $70(97.2)$ & \\
\hline $\begin{array}{l}\text { Menopausal } \\
\text { status }\end{array}$ & & & $\begin{array}{l}<0.001^{\mathrm{b}}, 0.32 \\
(0.22-0.46)\end{array}$ & & & $\begin{array}{l}<0.001^{\mathrm{b}}, 0.29 \\
(0.15-0.57)\end{array}$ \\
\hline Yes & $73(28.2)$ & $147(55.1)$ & & $19(17.9)$ & $31(43.1)$ & \\
\hline No & $186(71.8)$ & $120(44.9)$ & & $87(82.1)$ & $41(56.9)$ & \\
\hline $\begin{array}{l}\text { Employment } \\
\text { status }\end{array}$ & & & $\begin{array}{l}0.001^{\mathrm{b}}, 2.06 \\
(1.34-3.18)\end{array}$ & & & $\begin{array}{l}0.017^{\mathrm{b}}, 3.7(1.2- \\
11.4)\end{array}$ \\
\hline $\begin{array}{l}\text { Not em- } \\
\text { ployed }\end{array}$ & $164(69.5)$ & $197(82.4)$ & & $68(73.9)$ & $42(91.3)$ & \\
\hline Employed & $72(30.5)$ & $42(17.6)$ & & $24(26.1)$ & $4(8.7)$ & \\
\hline Smoking & & & $\begin{array}{l}0.040^{\mathrm{b}}, 0.32(0.1- \\
1.0)\end{array}$ & & & $0.630^{c}$ \\
\hline No & $181(97.8)$ & $172(93.5)$ & & $68(97.1)$ & $40(95.2)$ & \\
\hline Smoker & $4(2.2)$ & $12(6.5)$ & & $2(2.9)$ & $2(4.8)$ & \\
\hline $\begin{array}{l}\text { Radiotherapy } \\
\text { Hx }\end{array}$ & & & $0.811^{\mathrm{b}}$ & & & $1.000^{C}$ \\
\hline Yes & $16(6.3)$ & $18(6.8)$ & & $4(3.9)$ & $3(4.4)$ & \\
\hline No & $239(93.7)$ & $247(93.2)$ & & $99(96.1)$ & $65(95.6)$ & \\
\hline Cycle phase & & & $0.181^{\mathrm{b}}$ & & & $0.310^{C}$ \\
\hline Follicular & $64(52.5)$ & $33(63.5)$ & & $31(64.6)$ & $5(45.5)$ & \\
\hline Luteal & $58(47.5)$ & $19(36.5)$ & & $17(35.4)$ & $6(54.5)$ & \\
\hline
\end{tabular}

\footnotetext{
a Derived from

$\mathrm{b}$ Derived from Chi-square

${ }^{\mathrm{c}}$ Derived from Fisher Exact test
}

\subsection{Ovarian Cycle Phase}

According to cycle length and LMP (last menstrual period) date and the date of referral for mammographic examination, and considering the regularity of the cycle, menstrual cycle phase at the time of mammography was determined. Those with irregular cycles or incomplete information were not included in the analysis. Neither in screening nor the diagnostic group, had not any density associated to the cycle phase (Table 2).

\subsection{Employment Status}

In the screening group, the frequency of dense breasts among housewives (45.4\%), currently employed women (67.4\%) and employed or retired women (63.2\%) was compared and significant difference was demonstrated between the mentioned groups $(\mathrm{P}=0.016$ and $\mathrm{P}=0.017$ in sequence). in diagnostic group $61.8 \%$ of housewives had dense breasts which was significantly lower than dense breasts in currently employed $(87.5 \%, \mathrm{P}<0.001)$ and re- tired ones (85.7\%, P $<0.001)$.

\subsection{BMI}

BMI distribution in four ACR density categories is shown (Chart 1). In the screening group the mean BMI in high density breast group (26.8) was significantly less than that individuals with low breast density (28.9) and the difference was significant $(\mathrm{P}<0.001)$. In the diagnostic group the above mentioned association, did not exist.

\subsection{First Delivery Age}

Mean age at first delivery in screening group was 22.7 in high breast density group which was significantly $(\mathrm{P}<$ 0.001) higher than low breast density group (20.59) but in diagnostic group this amount was 21.6 and 20.3 years, respectively and the differences were not significant $(\mathrm{P}=$ $0.156)$. Mean breast density was significantly different in women with a first delivery age older and younger than 20 years old $(\mathrm{P}<0.001)$ and this difference was significant up to first delivery age of 29 . 


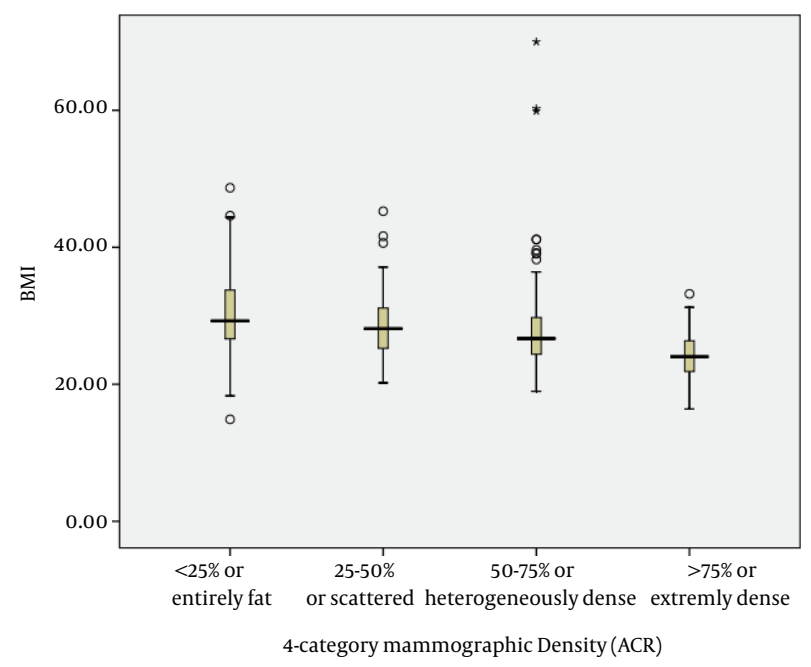

Figure 1. BMI Distribution According to Density

\subsection{Menopause age, Menarche age, Age at Last} Delivery and Cycle Length

None of the above mentioned factors showed association with breast density in neither diagnostic nor the screening groups (Table 2). Considering the fact that the association of some of these factors with breast density may affect it through some other ones, binary and mul- tiple logistic regression tests were administered to investigate the interactive effect of these factors on density. Binary logistic regression analysis showed that menopausal status, parity and age at the first delivery were independently associated with breast density (Table 3). Multiple logistic regression test revealed that only menopausal status had association with breast density ( $\mathrm{P}=$ 0.003).

Table 3. Results of Logistic Regression Analysis for Breast Density

\begin{tabular}{|c|c|c|c|c|c|c|}
\hline & \multicolumn{2}{|c|}{ Screening $(n=544)$} & \multicolumn{2}{|c|}{ Diagnostic $(n=184)$} & \multicolumn{2}{|c|}{ Total $(n=728)$} \\
\hline & $\begin{array}{l}\text { P-value, Un- } \\
\text { adjusted OR } \\
(95 \% C I)\end{array}$ & $\begin{array}{l}\text { P-value, } \\
\text { Adjusted OR } \\
(95 \% \mathrm{CI})\end{array}$ & $\begin{array}{l}\text { P-value, Un- } \\
\text { adjusted OR } \\
(95 \% C I)\end{array}$ & $\begin{array}{l}\text { P-value, } \\
\text { Adjusted OR } \\
(95 \% \mathrm{CI})\end{array}$ & $\begin{array}{l}\text { P-value, Un- } \\
\text { adjusted OR } \\
(95 \% \mathrm{CI})\end{array}$ & $\begin{array}{l}\text { P-value, } \\
\text { Adjusted OR } \\
(95 \% C I)\end{array}$ \\
\hline Age & $\begin{array}{l}<0.001,0.93 \\
(0.91-0.95)\end{array}$ & $\begin{array}{l}0.558,1.01(0.97- \\
1.07)\end{array}$ & $\begin{array}{l}<0.001,0.93(0.9- \\
0.97)\end{array}$ & $\begin{array}{l}0.921,0.997 \\
(0.942-1.056)\end{array}$ & $\begin{array}{l}<0.001,0.93 \\
(0.91-0.95)\end{array}$ & $\begin{array}{l}0.400,1.02 \\
(0.98-1.07)\end{array}$ \\
\hline BMI & $\begin{array}{l}<0.001,0.91 \\
(0.87-0.95)\end{array}$ & $\begin{array}{l}0.081,0.95(0.89- \\
1.00)\end{array}$ & $\begin{array}{l}0.188,0.96(0.91- \\
1.02)\end{array}$ & $\mathrm{NI}^{\mathrm{a}}$ & $\begin{array}{l}<0.001,0.93 \\
(0.89-0.96)\end{array}$ & $\begin{array}{l}0.196,0.97(0.93- \\
1.01)\end{array}$ \\
\hline Parity number & $\begin{array}{l}<0.001,0.71 \\
(0.63-0.81)\end{array}$ & $\begin{array}{l}0.011,0.66(0.48- \\
0.91)\end{array}$ & $\begin{array}{l}<0.001,0.74 \\
(0.63-0.88)\end{array}$ & $\begin{array}{l}0.167,0.85(0.68- \\
1.06)\end{array}$ & $\begin{array}{l}<0.001,0.73 \\
(0.66-0.81)\end{array}$ & $\begin{array}{l}0.025,0.75(0.62- \\
0.96)\end{array}$ \\
\hline First birth age & $\begin{array}{l}<0.001,1.1(1.05- \\
1.15)\end{array}$ & $\begin{array}{l}0.129,1.06(0.98- \\
1.15)\end{array}$ & $\begin{array}{l}0.159,1.06(0.98- \\
1.16)\end{array}$ & NI & $\begin{array}{l}<0.001,1.09 \\
(1.05-1.13)\end{array}$ & $\begin{array}{l}0.052,1.07(0.99- \\
1.15)\end{array}$ \\
\hline $\begin{array}{l}\text { Employment } \\
\text { status }\end{array}$ & 0.001 & 0.631 & 0.023 & 0.280 & $<0.001$ & 0.500 \\
\hline Housewife & 1 (ref) & 1 (ref) & 1 (ref) & 1 (ref) & 1 (ref) & 1 (ref) \\
\hline Employed & $2.06(1.33-3.18)$ & $1.19(0.59-2.39)$ & $3.71(1.20-11.43)$ & $1.98(0.57-6.85)$ & $2.15(1.45-3.19)$ & $1.24(0.67-2.30)$ \\
\hline Smoking & 0.050 & 0.289 & 0.603 & $\mathrm{NI}$ & 0.025 & 0.313 \\
\hline $\begin{array}{l}\text { Active } \\
\text { Smoker }\end{array}$ & $0.56(0.32-1.00)$ & $0.67(0.32-1.40)$ & $0.77(0.28-2.08)$ & NI & $0.55(0.33-0.93)$ & $0.73(0.39-1.35$ \\
\hline $\begin{array}{l}\text { No expo- } \\
\text { sure }\end{array}$ & 1 (ref) & 1 (ref) & 1 (ref) & & 1 (ref) & \\
\hline Marital status & 0.031 & 1.000 & 0.388 & & 0.021 & 1.000 \\
\hline Married & $0.41(0.18-0.92)$ & 0.000 & $0.55(0.14-2.14)$ & NI & $0.44(0.22-0.88)$ & 0.000 \\
\hline
\end{tabular}


Ahmadinejad $N$ et al.

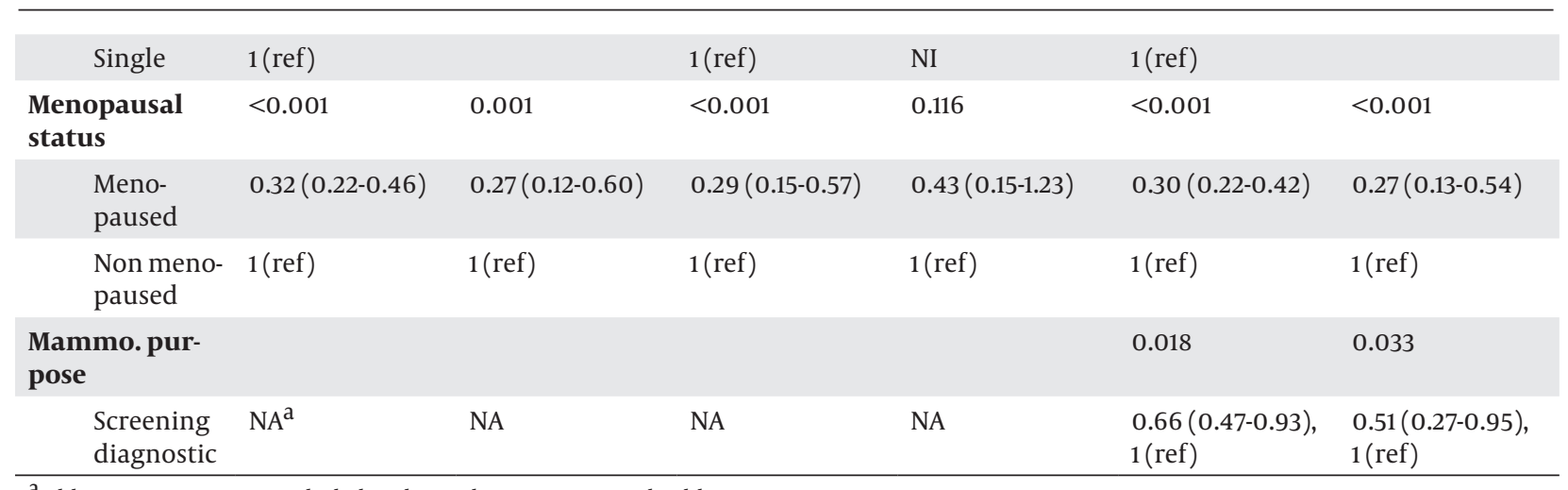

a Abbreviations: NI, Not included in the analysis; NA, Not applicable

\section{Discussion}

Study results showed that the majority of women were among ACR-BIRADS mammographic density categories II and III. The population of women with dense breasts (density $>50 \%$ ) were more than those with low breast density (51.9\% versus $48.1 \%$ ). In diagnostic group the proportion of dense breasts was significantly more than the screening ones.

It seems that Iranian population has denser breasts compared to what has been reported in studies in other countries. Wolf et al. (17) obtained a percentage of $25 \%$ dense breasts in the control group versus 37\% in the study group. In a case-control study carried out by Saftlas et al. (26), participants were divided into five density categories ( $<5 \%, 5-25 \%, 25-45 \% .45-65 \%$ and $>65 \%)$ and results revealed that $45 \%$ of cases and $32 \%$ of controls had mammographic density of $45 \%$ and higher (26-28). According to our study results, age, BMI, menopausal status, employment status, marital status, age at the first delivery, breast feeding, parity number and smoking showed association with density. Mammographic purpose and symptomatic or asymptomatic conditions were also related with density (29).

In younger age groups, the percentage of women with high density breasts is more than low density ones. As the age Increases, the breast density decreases is correlated with other studies $(16,20,23,26,30,31)$ Maximal breast density was observed in the age group 30-50 years old which correlates with their hormonal pattern. Density distribution differences between screening and diagnostic groups may have been due to some other confounding factors, which would affect density; on the other hand, there are theoretically differences between the two groups. Analysis comparing these factors in screening and diagnostic group revealed a significant difference concerning the age, personal history of breast cancer, using HRT and menopausal status. Among all these factors only age and menopausal status were associated with density which suggests that age and menopausal status may play a role as a confounder on the difference between diagnostic and screening group. Logistic regression test verified this claim. In other words diagnostic group contains dense breasts because it includes younger women and more proportion of premenopausal ones $(11,32,33)$.

Unlike parity and menopausal status, age was not independently associated with density. It seems that parity and menopausal status confound the relation of age and density, as claimed by Modugo et al. (30). They have shown by adjusting parity and BMI, no significant association between age and breast density were presented (34).

Unlike Modugo et al. (30) who demonstrated no association between density and breast feeding in Unites States, we found that the breast density was significantly more in those who had never experienced breast feeding and this suggests that breast feeding may change breast cancer risk by changing the breast density. Considering the fact that the mean parity number of women in developing countries is more than that reported in the United States, the above conflict is debatable. Thus, we suggest further studies focused on how duration of breast feeding affects the breast density. By comparing the mean age, no significant difference between those with and without breast feeding was observed $(35,36)$.

Breast density of premenopausal women was more than menopause group which can be due to the hormonal pattern. Regarding to this fact, we expected to discover an association between the use of HRT/OCP and breast density, as recommended in other studies $(20,24,31)$, but we did not. Because of limited number of hormone users in our study, besides the infeasibility of getting exact information about the certain duration of using hormones, the results are not enough reliable and it is necessary to design studies focusing on this association independently. The breast density was significantly more among nonsmokers. This may be due to age differences; but mean age of smokers and nonsmokers did not show any significant difference (37).

Employed women's breast density was significantly higher than housewives without a significant age difference. As most of employed women have physical activity with their hands and academic education, and are under stress more than others, this factors may affect this rela- 
tionship. There are few authors studying such factors. As an example we can name studies conducted in U.S. $(17,26$, 38 ) investigating on education. They proved that smoking and education had a reverse correlation with breast density in menopause women but not in premenopausal ladies $(26,39)$. According to our study outcomes, smoking seems to have the same effect, but having job associates with an increase in breast density.

Nulliparous women had denser breasts than the others and this difference is significant in woman with higher parity numbers (up to 8). This association can be explained by younger age of nulliparous women and by considering hormonal changes during each pregnancy. Comparing the age difference between these two groups, we found no significant difference $(40,41)$.

High breast density group showed older age at the first delivery. On the other hand, mean breast density was significantly different in women with the first delivery age older and younger than 20 years old and this difference was significant up to first delivery age of 29 . These findings correlate with the effects of first delivery age and breast cancer risk. Other studies $(20,26,30,31)$ reported similar findings. For example, nulliparity $(20,26,31,42)$ and first delivery at old age (31) are proved to be associated with an increase in breast density in menopause and premenopausal women. However some others have denied the association between first delivery age and breast density $(17,43)$.

Outer study, like other studies $(24,26,31,44)$ showed a reverse association between BMI and density. Breast density of those undergone mammography in follicular phase have not shown any significant difference with those in luteal phase and according to our results no specific time is suggested for mammographic examination. But because of pain in premenstrual period, this time is not recommended for mammography examinations.

\section{Acknowledgements}

This manuscript was derived from an MD-MPH thesis conducted by Sajjadeh Movahedinia, student of Medicine School, Tehran University of Medical Sciences, Iran. We would like to appreciate Mrs. Amjadi and Mrs. Teimuri, in mammography center of Imam Khomeini Cancer Institute, who help us to make this study possible. Our special thanks to Dr. Farzad Ranjpur, Dr. Abuzar Purrashidi, Dr. Elham Ahmadnejad, and medical student, Mohammad Movahedinia for their great assists which we could not have accomplished our study without their kind helps.

\section{Authors Contribution}

All authors have participated equally in this study.

\section{Funding/Support}

This research has been supported by Tehran University of Medical Sciences \& health Services 9 Nov. 2010.

\section{Financial Disclosure}

There is no conflict of interest.

\section{References}

1. World Health Organization. 2013. Available from: http://www. who.int/mediacentre/factsheets/fs297/en/.

2. Boyle P, Levin B. World Cancer Report, France. World Health Organization; 2008.

3. Parkin DM, Bray F, Ferlay J, Pisani P. Global cancer statistics, 2002. CA Cancer J Clin. 2005;55(2):74-108.

4. Wilson CM, Tobin S, Young RC. The exploding worldwide cancer burden: the impact of cancer on women. Int J Gynecol Cancer. 2004;14(1):1-11.

5. Goya M. Iranian Annual Cancer Registration Report. Tehran, Iran; 2007.

6. Mousavi SM, Gouya MM, Ramazani R, Davanlou M, Hajsadegh $\mathrm{N}$, Seddighi Z. Cancer incidence and mortality in Iran. Ann Oncol. 2009;20(3):556-63.

7. Pu L, Jing S, Bianqin G, Ping L, Qindong L, Chenggui L, et al. Development of a Chemiluminescence Immunoassay for Serum YB-1 and its Clinical Application as a Potential Diagnostic Marker for Hepatocellular Carcinoma. Hepat Mon. 2013;13(7).

8. Harirchi I, Karbakhsh M, Kashefi A, Momtahen AJ. Breast cancer in Iran: results of a multi-center study. Asian Pac J Cancer Prev. 2004;5(1):24-7.

9. Mousavi SM, Montazeri A, Mohagheghi MA, Jarrahi AM, Harirchi I, Najafi M, et al. Breast cancer in Iran: an epidemiological review. Breast J. 2007;13(4):383-91.

10. Harirchi I, Ebrahimi M, Zamani N, Jarvandi S, Montazeri A. Breast cancer in Iran: a review of 903 case records. Public Health. 2000;114(2):143-5.

11. Moradi M, Ganji K, Teyfouri N, Kolahdoozan F. Performance of double reading mammography in an Iranian population and its effect on patient outcome. Iran J Radiol. 2013;10(2):51-5.

12. Elmore JG, Armstrong K, Lehman CD, Fletcher SW. Screening for breast cancer. JAMA. 2005;293(10):1245-56.

13. Boyd NF, Byng JW, Jong RA, Fishell EK, Little LE, Miller AB, et al Quantitative classification of mammographic densities and breast cancer risk: results from the Canadian National Breast Screening Study. J Natl Cancer Inst. 1995;87(9):670-5.

14. Byrne C, Schairer C, Wolfe J, Parekh N, Salane M, Brinton LA, et al. Mammographic features and breast cancer risk: effects with time, age, and menopause status. J Natl Cancer Inst 1995;87(21):1622-9.

15. McCormack VA, Highnam R, Perry N, dos Santos Silva I. Comparison of a new and existing method of mammographic density measurement: intramethod reliability and associations with known risk factors. Canc Epidemiol Biomarkers Prev. 2007;16(6):1148-54

16. Nadrljanski MM, MarkoviÄł BB, MiloÅjeviÄt ZÄ. Breast Ductal Carcinoma in Situ: Morphologic and Kinetic MRI Findings. Iran J Radiol. 2013;10(2):99-102.

17. Wolfe JN, Saftlas AF, Salane M. Mammographic parenchymal patterns and quantitative evaluation of mammographic densities: a case-control study. AJR Am J Roentgenol. 1987;148(6):1087-92.

18. Farrokh D, Hashemi J, Ansaripour E. Breast hamartoma: mam mographic findings. Iran J Radiol. 2011;8(4):258-60.

19. Nawawi O, Ying Goh K, Rahmat K. A rare case of primary infiltrating neuroendocrine carcinoma of the breast. Iran J Radiol. 2012;9(4):212-6.

20. Azarian A, Mohammadifard M. Analysis of the Factors, Effective on Breast Parenchymal Density in Mammogram. Iran J Obstet. 2008;11(1):9-16.

21. Sirus M, Golshahi Z, Talayi S, Oshaghi F. Correlation of Asymmetric Breast Density Findings in Mammograms with Cytologic Findings. Iran J Radiol. 2005;3(S1):1-2.

22. Silanian F. The effect of HRT on sensitivity of screening mammographic in menopause women. Mazandaran University Med J. 2004;14(42):76-83.

23. Kerlikowske K, Ichikawa L, Miglioretti DL, Buist DS, Vacek PM, 


\section{Ahmadinejad $N$ et al.}

Smith-Bindman R, et al. Longitudinal measurement of clinical mammographic breast density to improve estimation of breast cancer risk. J Natl Cancer Inst. 2007;99(5):386-95.

24. Titus-Ernstoff L, Tosteson AN, Kasales C, Weiss J, Goodrich M, Hatch EE, et al. Breast cancer risk factors in relation to breast density (United States). Canc Causes Control. 2006;17(10):1281-90.

25. Liberman L, Abramson AF, Squires FB, Glassman JR, Morris EA, Dershaw DD. The breast imaging reporting and data system: positive predictive value of mammographic features and final assessment categories. AJR Am J Roentgenol.1998;171(1):35-40.

26. Saftlas AF, Hoover RN, Brinton LA, Szklo M, Olson DR, Salane M. Mammographic densities and risk of breast cancer. Cance Causes Control.1991;67(11):2833-38.

27. Yu-Mei L, Hsueh-Hua Y. Demographic Factors Influencing Consensus Opinion on the Recall for Women Screened by Mobile Mammography Unit in Taiwan. Iran J Radiol. 2013;10(3):116-121.

28. Marinelli S, Granito A, Piscaglia F, Renzulli M, Stagni A, Bolondi L. Metronomic Capecitabine in Patients With Hepatocellular Carcinoma Unresponsive to or Ineligible for Sorafenib Treatment: Report of Two Cases. Hepat Mon. 2013;13(9).

29. Sanjari S, Naderifar A, Pazuki G. Modeling and Optimization of $\beta$-Cyclodextrin Production by Bacillus licheniformis using Artificial Neural Network and Genetic Algorithm. Iran J Biotech. 2013;11(4):223-232.

30. Modugno F, Ngo DL, Allen GO, Kuller LH, Ness RB, Vogel VG, et al. Breast cancer risk factors and mammographic breast density in women over age 70. Breast Canc Res Treat. 2006;97(2):157-66.

31. Vachon CM, Kuni CC, Anderson K, Anderson VE, Sellers TA. Association of mammographically defined percent breast density with epidemiologic risk factors for breast cancer (United States). Canc Causes Control. 2000;11(7):653-62.

32. Nadrljanski MM, MarkoviÄț BB, Milo̊̊jeviäł ZÄ. Breast Ductal Carcinoma in Situ: Morphologic and Kinetic MRI Findings. Iran J Radiol. 2013;10(2):99-102.
33. Aras M, Ones T, Dane F, Nosheri O, Inanir S, Erdil TY, et al. False Positive FDG PET/CT Resulting from Fibrous Dysplasia of the Bone in the Work-Up of a Patient with Bladder Cancer: Case Report and Review of the Literature. Iran J Radiol. 2013;10(1):41-44.

34. Moradi M, Ganji K, Teyfouri N, Kolahdoozan F. Performance of Double Reading Mammography in an Iranian Population and Its Effect on Patient Outcome. Iran J Radiol. 2013;10(2):51-5.

35. Dadashpour Davachi N, Miri SM. Embryo Culture Challenge: Microbial Contamination. Iran J Biotech. 2013;11(4):207-208.

36. Zeinoaldini S, Jafari Z, Sarmast F, Torbati E, Dadashpour Davachi N. Different Harvesting Techniques Used in Ovine in vitro Embryo Production. Scimetr. 2013;1(1).

37. Rahmani MM, Shakiba B, Ameli M. Management of an Extremely Long Foreign Body in the Urethra and Bladder of a 13-Year-old boy: A Case Report. Thrita. 2013;2(1):35-37.

38. Sabzi Sarvestani A, Zamiri M. Presacral Schwannoma Causing Infertility in a Young Woman: Report of a Case. Scimetr. 2013;1(1).

39. Khazan M, Azizi F, Hedayati M. A Review on Iodine Determination Methods in Salt and Biological Samples. Scimetr. 2013;1(1).

40. Valadkhani Z, Hassan N, Aghighi Z. A Survey Study of Trichomonas Vaginalis Infection in Unmarried Male Referred to Farmanfarmaean Clinic. Scimetr. 2013;1(1).

41. Fayaz S, Fard-Esfahani P, Khaghani S. Development of a High-Resolution Melting Method for Screening R188H Polymorphism in XRCC2 Gene. Iran J Biotech. 2013;11(2):104-8.

42. Trinh DK, Quyen DT, Do TT, Huong Nguyen TT, Nghiem NM. Optimization of Culture Conditions and Medium Components for Carboxymethyl Cellulase (CMCase) Production by a Novel Basidiomycete Strain Peniophora sp. NDVN01. Iran J Biotech. 2013;11(4):251-259.

43. Zheng Y, Zhang S, Tan Grahn HM, Ye C, Gong Z, Zhang Q. Prophylactic Lamivudine to Improve the Outcome of Breast Cancer Patients With HBsAg Positive During Chemotherapy: A Meta-Analysis. Hepat Mon. 2013;13(4). 